\title{
Kazakhs and modern city space (on the example of Ust-Kamenogorsk)
}

\section{DOI: 10.31551/2410-2725-2018-4-4-558-575}

\section{Sarsembayeva Gulzhan Alibekovna}

Candidate of historical Sciences, associate Professor of East Kazakhstan state technical University. By D.Serikbaev. Kazakhstan, 070000, Ust-Kamenogorsk, St. Serikbayev, 19. E-mail: Gulzhan1974@mail.ru.

\begin{abstract}
The article provides an analysis of the urban Kazakh population in the modern period. Based on the interview, the author examines the opinions of the urban Kazakhs who are partially or fully assimilated and integrated in the cities. The interview included questions characterizing the presence of modern and traditional attitudes in the behavior of the designated cohort of the urban Kazakh population (compliance with national customs and traditions, communication with relatives, attitudes towards manifestations of cronyism and the preservation of the "big family"), language preferences, peculiarities of interethnic communication, and features of interaction with other groups of Kazakhs living in the city. A separate block of interviews comprised questions revealing the attitude of the respondents to the transformations of the modern urban space: visual, onomastic, ethnic and others.

The paper presents conclusions about the differentiation of the urban Kazakh population, and also outlines the proposed scenarios for the further development of urban space by autochthons. The first of the scenarios is the Russification of the Kazakh urban population, the dissolution of ethnic identity and language in the urban space (movement from the traditional to the modern). The next development option is the ruralization of the city (movement from the modern to the traditional), when the city begins to live not according to the established standard and the usual logic of development, but according to the situation in which the modern urban thinking is increasingly giving way to the generic one. The third scenario: on the basis of the former social structure of the city - the transformation of its individual elements (ethnic, cultural, economic), creating the prerequisites for a kind of synthesis of mutual coexistence in the same urban space as the Russian language and culture, and Kazakh, in part, with elements of westernization.
\end{abstract}

Keywords: city; migration; urbanization; ethnicity; assimilation; integration; onomastics.

\section{Казахи и современное городское пространство (на примере г. Усть-Каменогорска)}

\section{Сарсембаева Гульжан Алибековна}

кандидат исторических наук, доцент Восточно-Казахстанского государственного технического университета имени Д.Серикбаева. Казахстан, 070000, г. Усть-Каменогорск, ул. Серикбаева, 19. E-mail: Gulzhan1974@mail.ru.

Аңдатпа. Мақалада қазіргі кезеңдегі қалалық қазақ халқының талдауы берілген. Автор сұхбат негізінде қалаларда интеграцияланған және ішінара немесе толық ассимиляцияланған қала қазақтарының пікірлерін зерттейді. Сұхбатқа қалалық қазақ халқының белгіленген қоғамындағы қазіргі заманғы және дәстүрлі ұстанымдардың бар болуын (ұлттық салт-дәстүрлерді сақтау, туыстарымен қарым-қатынас жасау, «үлкен отбасын» сақтау мен рулық көріністеріне қарымқатынас жасау), тілдік артықшылықтар, ұлтаралық қарым-қатынас ерекшеліктері, сондай-ақ қалада тұратын қазақтардың басқа топтарымен өзара іс-қимыл жасау ерекшеліктері туралы сұрақтар енгізілді. Сұхбаттың жеке бөлігі респонденттердің қазіргі заманғы қалалық кеңістіктің: визуалды, ономастикалық, этникалық және т.б. өзгерулеріне қатынасын ашатын сұрақтар болды.

Жұмыста қалалық қазақ халқының саралануы туралы қорытындылар берілген, сондай-ақ қалалық кеңістікті ежелгі тұрғындармен одан әрі игерудің болжамды сценарийлері белгіленген. Сценарийлердің бірі - қазақ халқының орыстануы, қалалық кеңістікте этникалық өзіндік болмысы мен тілінің еруі (дәстүрден қазіргі заманға дейінгі қозғалыс). Дамудың келесі нұсқасы - қалада қалыптасқан стандарт пен үйреншікті даму логикасы бойынша өмір сүре бастаған кезде, ал қазіргі қалалық ойлау рулық орынға жиі жол беретін жағдай бойынша қаланы рурализацияландыру (қазіргі заманнан дәстүрлі даму қозғалысы).Үшінші сценарий: қаланың бұрынғы әлеуметтік құрылымы негізінде - орыс тілі мен мәдениетінің, сондай-ақ қазақ тілі мен мәдениетінің бір қалалық кеңістігінде өзара қатар өмір сүрудің өзіндік синтезі үшін алғышарттар жасайтын оның жекелеген элементтерінің (этникалық, мәдени, экономикалық) өзгеруі.

Түйін сөздер: қала; көші-қон; урбанизация; этнос; ассимиляцияландыру; интеграцияландыру; ономастика. 


\title{
Казахи и современное городское пространство (на примере г. Усть-Каменогорска)
}

\section{Сарсембаева Гульжан Алибековна}

кандидат исторических наук, доцент Восточно-Казахстанского государственного технического университета имени Д.Серикбаева. Казахстан, 070000, г. Усть-Каменогорск, ул. Серикбаева, 19. E-mail: Gulzhan1974@mail.ru.

Абстракт. В статье дан анализ городского казахского населения в современный период. Автором на основе интервью исследуются мнения городских казахов частично или полностью ассимилировавшихся и интегрировавшихся в городах. В интервью вошли вопросы, характеризующие наличие современных и традиционных установок в поведении обозначенной когорты городского казахского населения (соблюдение национальных обычаев и традиций, общение с родственниками, отношение к проявлениям клановости и сохранению «большой семьи»), языковые предпочтения, особенности межнационального общения, а также особенности взаимодействия с другими группами казахов, проживающих в городе. Отдельный блок интервью составили вопросы, раскрывающие отношение респондентов к преобразованиям современного городского пространства: визуальным, ономастическим, этническим и прочим.

В работе представлены выводы о дифференцированности городского казахского населения, а также намечены предполагаемые сценарии дальнейшего освоения городского пространства автохтонами. Первый из сценариев - русификация казахского городского населения, растворение этнической самобытности и языка в городском пространстве (движение от традиционного к современному). Следующий вариант развития - рурализация города (движение от современного к традиционному), когда город начинает жить не по устоявшемуся стандарту и привычной логике развития, а по ситуации, в которой современное городское мышление всё чаще уступает место родовому. Третий сценарий: на основе прежней социальной структуры города - трансформация его отдельных элементов (этнических, культурных, экономических), создающая предпосылки для своеобразного синтеза взаимного сосуществования в одном городском пространстве как русского языка и культуры, так и казахского, отчасти, с элементами вестернизации.

Ключевые слова: город; миграция; урбанизация; этнос; ассимиляция; интеграция; ономастика.

\section{ӘОЖ / УДК 94 (574.42)}

\section{Казахи и современное городское пространство (на примере г. Усть-Каменогорска)}

\author{
Сарсембаева Г.А.
}

Введение. Тенденции процесса урбанизации казахов начали проявлять себя со второй половины XX века. Однако в 1950-80-е годы миграционный поток титульного населения в город был не очень велик. Главной причиной являлось то, что долгое время казахстанский город был европеизированным, мало чем отличавшимся, например, от города российского. Урбанизация в определенной мере подразумевала под собой русификацию, а восприятие стандартов города - отказ от традиционного сельского уклада жизни. Приезжие были вынуждены приспосабливаться к городской среде и уже во втором поколении становились русскоязычными. Поэтому, на уровне этнического подсознания казахи, оберегая себя от русификации, потери национальной самобытности, по мере возможности оставались проживать в сельской местности. Таким образом, до начала 1990-х годов урбанизация казахов отличалась малочисленностью, плавностью и предсказуемостью.

Экономический кризис, разразившийся в конце XX в., а также провозглашение суверенитета республики внесли изменения в эволюционные процессы миграционного потока «село - город». Людской потенциал, долгое время копившийся в селах Казахстана, пришел в движение и устремился в 
город. Активизация сельско-городской миграции оголила многие проблемы, которые сформировались еще в советский период и были связаны с этнической поляризацией расселения населения Казахстана. Так, стало явным наличие двух «параллельных миров»: стандартизированного, европеизированного города и традиционного казахского села, существовавших автономно и не так часто пересекавшихся. Поэтому, при входе миграционных потоков в города происходила встреча не просто двух пространственно локализованных социокультурных миров, но и двух этнически разнородных субстратов. Казахимигранты как носители сельской, традиционной культуры, прибывая в города, были вынуждены осваивать иные, чуждые им культурные ценности и стереотипы, социальные роли и образ жизни, присущие как собственно городской субкультуре, так и культуре доминирующей городской этногруппы. Сказанное явилось причиной того, что сельские мигранты сталкивались с проблемами не только социально-экономического, но и этнопсихологического характера. Сельчане во многом отличаются от жителей, родившихся и выросших в городе. Пройдя первоначальную социализацию в сельской местности, они привносят в город присущие им системы ценностей, психологию, стереотипы и установки, особые потребности, отличающие их от горожан. Все это затрудняет вхождение в урбанизированную субкультуру, вызывает целый комплекс негативных психологических эмоций. Неслучайно, в анализируемое время проявляет себя еще одна немаловажная проблема, связанная с адаптацией сельчан к городскому укладу жизни. Речь идет об установках сельского жителя на восприятие особенностей городских стандартов и городской культуры. В советское время город ставил мигрантасельчанина перед необходимостью русифицироваться, принятия городской культуры и образа жизни в целях его быстрой адаптации и достижения поставленных целей. В 1990-е гг. значительная часть казахов, массово мигрировавшая в города, не видела уже такой необходимости в связи с компактным расселением: сельчане зачастую занимали целые пригородные районы и частные городские секторы.

«Обширный поток сельских мигрантов, «затапливающий» города республики, привел к тому, что урбанизация все более походила по своим последствиям на процессы рурализации. Уже не столько сельские мигранты осваивали урбанизированную субкультуру, сколько города, будучи не способными «растворить» миграционный поток, становились объектами интродукции традиционной сельской культуры, то есть начинали жить по правилам, стереотипам и логике сельской жизни, подчиняясь ее нормам и установкам. Выражением этой тенденции становились и участившиеся случаи «обратной» маргинализации городских жителей. Уже они были вынуждены адаптироваться, осваивать или, по крайней мере, принимать к сведению ментальность, характерную для стереотипов сельского общества. Сказанное поставило под угрозу сохранение эндогенной городской культуры, особенностей урбанизированного образа жизни, в целом, облика города». (Сарсембаева, 2000:335)

Ситуация усугублялась крахом социальной городской инфрраструктуры, остановкой предприятий, эмиграцией «старого» городского населения. Необходимо отметить, что существует тесная связь между внутренней и внешней миграцией - активизация первой воздействует на интенсивность последней. Эмиграция городских жителей в начале суверенного периода была отчасти обусловлена этническим характером сельско-городского движения, 
которое «выдавливало» в города с большей концентрацией европейского населения или в целом из страны.

Таким образом, экономические трудности начала суверенного периода внесли большие изменения в характер и интенсивность сельско-городской миграции. Если в досуверенное время сельские казахи, переезжающие в города, сознательно стремились к смене сельского образа жизни на городской, то в начале 1990-х годов добровольный характер миграции сменился на вынужденно-безысходный. Несоразмерно с досуверенным периодом увеличиваются масштабы потока «село - город». Необходимо отметить, что экономический кризис затронул, не только села, но и города страны. Оказавшийся не готовым растворить огромную массу сельских мигрантов, казахстанский город 1990-х годов предоставлял минимум возможностей для адаптации сельчанина. Не имея реальных шансов для относительно быстрой и безболезненной интеграции в городскую среду, сельские жители расселялись компактно, стремясь сохранить собственную сельскую субкультуру, вносили изменения в городские стандарты и стереотипы жизни.

На сегодняшний день вынужденный, непредсказуемый и массовый характер сельской миграции постепенно уступает место планомерному, сознательному процессу урбанизации сельчан. Сельские жители, постепенно адаптируясь и интегрируясь в городскую среду, находят свои ниши в сорере занятости. Процесс стихийной урбанизации выработал определенные закономерности, предоставляя возможности для дальнейшего его прогнозирования.

В целом за период с 1989 г. по 2009 г. численность городских казахов выросла на 93,2\%, удельный вес горожан в структуре этноса поднялся на $24,7 \%$. В 2009 г. численность казахов, проживающих в городах, составила 4841,1 тыс. человек или 47,9\% этноса. В структуре же всего городского населения страны их удельный вес увеличился до 55,9\%. (Статистический, 1991:13-15; Национальный,2000:15-32; Этнодемографический, 2006:5; Перепись, 2010:17,23 )

В настоящее время казахов можно назвать урбанизированным этносом, около половины численности которого составляет городское население. Как отметил Н.А. Назарбаев: «Мало кто обратил внимание на то, что за 15 лет казахи стали подлинно урбанизированной нацией не только по статистике, но и по существу... Этот сдвиг принципиально важен для понимания того, что происходит в обществе. Уровень национального статуса и национальной самооценки казахов стал соответствовать статусу государствообразующей нации». (Назарбаев, 2006)

Быстрые темпы формирования «нового города» обусловили концентрацию в нем различных социальных групп автохтонов. Структура городского казахского населения, на взгляд автора, следующая. Прежде всего, это бывшие сельские жители, не так давно мигрировавшие в город и находящиеся на начальном этапе урбанизации (самая многочисленная категория казахского городского населения). Активизация потока рассматриваемых мигрантов, особенно средних возрастов, была связана с востребованностью их, в связи с владением государственным языком, в некоторых профессиональных нишах (властные и силовые структуры, образование, здравоохранение), а также со всё расширяющейся сферой услуг и торговли.

В структуре современного городского казахского населения присутствует также немногочисленная когорта переехавших в город еще в советское время. Это, как правило, представители старших возрастных групп и их дети (внуки). 
И, если первых можно отнести к частично ассимилировавшимся, то вторых (детей, которые находятся на сегодняшний день в среднем возрасте) - можно считать полностью обрусевшими (интеграция в городское пространство в советский период, в связи с большой концентрацией русского этноса в городах, подразумевала ассимиляцию казахов, их обрусение).

Между названными полярными когортами городских казахов находятся «маргинальные группы», демонстрирующие как городские, так и сельские особенности образа жизни. Это, прежде всего, казахи, переехавшие в город в 1990-е годы (численность их в городах также существенна). Степень их урбанизированности во многом зависит от того, откуда они мигрировали (из села или районного центра, малого города), от расселения в городе (центре, пригороде, дачном поселке), а также от сферы, в которой они заняты (торговля, образование, здравоохранение, государственные структуры и пр.).

Отдельную группу представляют казахи молодых возрастов, рожденные и социализировавшиеся в городе. Родителями их, в основе своей, являются мигрировавшие в 1990-е годы в города сельские жители. Это первое статистически значимое поколение, представители которого постепенно входят в репродуктивный возраст и начинают воспроизводить себя в городе. Еще через 25 лет, когда у данной возрастной когорты появятся внуки и будут присутствовать три поколения казахов, рожденных в городе, можно утверждать о полноценном становлении городской казахской нации.

Bce перечисленные группы казахского населения, которые, ко всему прочему, внутри не являются однородными, сосуществуют в современном городском пространстве. Суть проблемы заключается не в изучении хронологии, эволюции формирования групп, а в анализе их взаимодействия. В данном контексте наиболее эфффективными являются социологические методы исследования (интервью, анкета, опрос, беседа). Использование социологических методов продиктовано также необходимостью фриксации сложившейся в современном городском пространстве ситуации, которая не является статичной и каждый день меняется. Исторические методы можно будет использовать впоследствии, когда процесс формирования городской казахской нации будет близок к завершению.

Представленная статья является составной частью исследования особенностей взаимодействия всех перечисленных выше групп городского казахского населения и их влияния на трансформации города. Для анализа обозначенных эволюций автором был выбран г. Усть-Каменогорск, являющийся одним из крупных городов восточного региона страны. Европеизированность (в этническом отношении) казахстанских городов советского периода в Усть-Каменогорске также, как и в остальных городах Восточного, Северного, отчасти Центрального регионов, проявлялась более гротескно. Так, в 1959 г. в городе проживало всего 4,4\% казахов, в 1989 г 10,6\%. В суверенное время (данные статистики за 2014 г.) городское казахское население составило $38,3 \%$ в общей структуре жителей Усть-Каменогорска. (Итоги, 1962:13; 8; 9)

Проблематику статьи составило изучение установок и мнений отдельной когорты казахов-горожан, а именно, частично или полностью интегрировавшихся в городском пространстве, полученные в ходе интервью. В интервью приняли участие респонденты возрастной категории 19-56 лет студенты, преподаватели вузов и колледжей, врачи, с рождения или большую часть жизни проживающие в городе. 
Вопросы интервью выявляли наличие традиционных и/или современных установок в поведении; в межнациональном общении; предпочтений в языке. Отдельный блок вопросов вскрывал особенности взаимодействия отмеченной категории населения с другими группами городских казахов. В интервью также вошли вопросы по изучению отношения к преобразованиям современного городского пространства: визуальным, ономастическим, этническим и пр.

Таким образом, в настоящее время идет смена сути городского пространства Казахстана. В течение XX века векторы развития определяло европейское население. Немногочисленные горожане-казахи встраивались в сорормированные европейские городские стандарты, почти не привнося в них каких-либо «этнических нюансов». В конце XX - начале XXI вв. особенности эволюции городского пространства определяли взаимоотношения «старого» городского населения, русских массе своей, - со сменившими место жительства автохтонами. В конце «десятых» годов XXI в. «межэтническая» составляющая функционирования города в основном остается в прошлом. Большинством городского населения республики впервые в своей истории являются казахи, именно они теперь определяют векторы развития городского пространства. В результате, все большее значение имеют отношения уже среди казахов, в разное время прибывших в города. Данная тенденция набирает темп и способна определять ситуацию в долгой перспективе.

\section{Шала-казахи: традиционное или современное?}

В данный блок вошли вопросы, определявшие наличие традиционных и современных установок в поведении исследуемой когорты городского населения.

Гульжан Сарсембаева (Г.С.) «Соблюдаете ли вы национальные традиции и обычаи?»:

«Не все, только некоторые из них. В иелом соблюдаю не обряды и обычаи, а национальные этические нормы поведения. Например, уважительное отношение к старшим, женщине. В общественном транспорте всегда уступаю место старикам. Но такую национальную традицию, как гостеприимство, не соблюдаю. Мне проще встретиться с человеком в кафре, нежели приглашать его к себе домой в гости» (Амантай, 56 лет, педагог).

«В целом, нет. Но стараюсь соблюдать две самые главные традиции казахов - почтительное отношение к старшим по возрасту и традицию гостеприимства. Но иногда это трудно. Я говорю о гостеприимстве. Не все понимают и злоупотребляют этим» (Айман, 44 года, педагог).

Респонденты указывают, что не соблюдают или же формально соблюдают национальные традиции и обычаи. Более того, большая часть опрашиваемых отметила неактуальность такой основополагающей традиции казахов, как гостеприимство, продемонстрировав в своих ответах нежелание её соблюдать, отрицательное отношение к приходу гостей, приезду родственников из села:

«Нежелательно» (Зарина, 42 года, педагог);

«Они знают, что я плохо к этому отношусь, поэтому не приезжают» (Амантай, 56 лет, педагог);

«Конечно, я буду гостеприимной, но нежелательно часто приезжать им» (Айман, 44 года, педагог).

Еще один вопрос, выявляющий наличие или отсутствие традиционных установок в поведении городских казахов - «Часто ли вы общаетесь со своими родственниками (близкими, дальними), проживающими в городе и селе?». 
«С родителями и близкой родней вижусь раз в 2-3 месяца. С остальными родственниками несколько раз в год на семейных мероприятиях, как правило, на свадьбах или юбилеях» (Айман, 44 года, педагог).

«С родителями вижусь почти каждый день. C родственниками же общаюсь только с теми, кого хорошо знаю и с кем поддерживал отношения с детства... Сейчас у многих нет большого обеденного стола. Они не собираются вместе ни за обедом, ни за ужином. Кушают, когда кому вздумается, по отдельности. Поэтому иногда не в курсе, что у кого происходит» (Амантай, 56 лет, педагог).

Исходя из ответов видно, что представители данной группы городского населения поддерживают связь с узким кругом близких родственников. Совместные мероприятия с представителями «большой семьи» (близкие и дальние родственники) проводятся редко. Зачастую, в близкий круг друзей или даже родственников городских казахов-старожилов входят представители других национальностей.

Однако почти все опрашиваемые отметили, что испытывают в той или иной степени необходимость в поддержке родственников, клана:

«Все казахи, которых я знаю, близки со своими родственниками» (Айжан, 46 лет, врач);

«Когда есть необходимость поездок в другие города, родственники выручают, есть, где остановиться» (Сымбат, 48 лет, педагог);

"Я устроилась на работу при помощи родственника. И многие так. Когда мне нужны были деньги на первоначальный взнос за квартиру, а деньги немалые, то выручила сестра. Когда заболею, выручает другая сестра. Брат привозит продукты из дома» (Айман, 44 года, педагог).

Ответы интервью демонстрируют актуальность использования ресурса родственников, «большой семьи»:

«Когда устраивалась на работу, я попыталась сама, но работы нигде не было. Пришлось родителям обратиться за помощью к агашке. Он все устроил в лучшем виде» (Айман, 44 года, педагог);

«Практически все, кто из села, работают сейчас в системе образования, акиматах и прочее, устроились туда через агашек» (Айжан, 46 лет, врач).

В тоже время, большая часть опрашиваемых демонстрирует негативное отношение к использованию ресурса родственников, в целом, всё еще популярной среди казахов, в том числе городских, традиции существования «института агашек»:

«Отношение негативное. Но что поделать...» (Айман, 44 года, педагог); «Если у тебя нет денег или агашки, что сидит где-то там, ты никто, даже если ты умный, хороший профрессионал» (Лаура, 20 лет, студентка).

Отмечается большой разброс ответов на вопрос, касающийся знания шежире рода;

«Нет, не знаю. Никогда этим не интересовалась» (Айжан, 46 лет, врач);

«Знаю только какого казахского рода мои родители, как звали моих бабушек и дедушек» (Айман, 44 года, педагог);

«Да, знаю с детства» (Амантай, 56 лет, педагог).

Один из важных вопросов интервью - вопрос о языковых предпочтениях. Ответы показали, что большая часть опрашиваемых почти во всех ситуациях отдает предпочтение русскому языку:

«Я обрусевшая казашка, но изучаю родной язык. Почти всегда говорю на русском языке» (Айман, 44 года, педагог); 
«Мне комфортно находиться там, где говорят на русском языке, потому что я лучше знаю русский язык» (Сымбат, 48 лет, педагог);

«Говорю в основном по-русски, но когда надо, могу перейти на казахский» (Амантай, 56 лет, педагог);

«Я сама в основном свои мысли довожу на русском, на казахском некоторые слова не понимаю» (Лаура, 20 лет, студентка).

Русский язык доминирует также в выборе телепередач, газет и журналов:

«Лично я смотрю в основном российские каналы (ОРТ, Россия 1, НТВ, РенTB), также европейские и американские каналы (Fox, TLC). Bce на русском языке» (Назерке, 20 лет, студентка);

«Телевизор почти не смотрю, в основном сижу в интернете. На русском языке» (Тимур, 19 лет, студент).

Г.С. «Как вы думаете, почему, несмотря на значительный миграционный отток русского (русскоязычного) населения из городов республики, русский язык по-прежнему продолжает оставаться наиболее распространенным языком общения, в том числе, среди казахского этноса?»:

«Многие казахи воспринимают русский язык как язык городской нации и поэтому, чтобы считать себя полноправным горожанином, освачвают и говорят на нем. Это, наверное, главная причина. Есть еще и другие причины. Например, в Усть-Каменогорске по-прежнему многочисленно русское (русскоязычное) городское население. Также немаловажное значение имеет система занятости. Экономические ниши, промышленные предприятия, представлены до сих пор русскими. Чтобы «пролезть» в определенные экономические ниши необходимо знание русского языка» (Айман, 44 года, педагог).

«Я часто слышу критику в свой адрес из-за плохого владения родным языком. Но я с детства говорю по-русски. Другому языку меня не учили. Сейчас иногда даже на улице могут сделать замечание. Раньще я комплексовала из-за этого. Пыталась говорить по-казахски. Плохо получалось. А сейчас решила, что единственный язык, на котором я могу говорить, нормально общаться - это русский. Поэтому говорю только на нем. И по улице иногда иду и специально громко говорю по-русски. Русский язык выжил у нас по этой причине. Если бы не навязывали знание гос. языка, не делали бы постоянные замечания ... » (Сымбат, 48 лет, педагог).

«Русский язык же простой. Много быстро запоминающихся коротких слов и нет звуков, таких как в казахском языке» (Тимур, 19 лет, студент).

Как уже отмечалось, большая часть опрашиваемых почти во всех ситуациях отдает предпочтение русскому языку. В качестве аргументов высказываются мнения о том, что русский язык - это язык городской нации, что он прост в изучении и произношении, лаконичен, не является интонационным, практически не имеет специфических звуков. Некоторые респонденты отметили, что сегодня говорить по-русски, использовать старые названия улиц может означать своеобразный городской шик.

Следующий вопрос выявлял отношение респондентов к русскоговорящим автохтонам: «Как вы относитесь к тому, что многие горожане-казахи говорят на русском языке? На ваш взгляд, с чем это связано?».

«Отношусь нормально. Но родной язык знать тоже надо, необходимо. То, что многие продолжают говорить по-русски в городах связано с тем, что они взрослели в советскую эпоху, когда русский язык был единственным языком общения в городе» (Айжан, 46 лет, врач). 
«Говорят на русском в основном обрусевшие казахи или их дети. Для меня ситуация понятна и приемлема, если русский язык единственный родной у таких казахов. Сама такой являюсь. Но есть еще и те, кто хорошо владеет казахским. Им то что говорить по-русски? Иногда можно услышать русскую речь с акцентом. Хочется сказать таким: чем говорить на русском с акцентом, говорите лучше по-казахски, но чисто. Вообще, русский язык переживает в городах страны как бы реинкарнацию. Он становится все более и более популярен среди казахов» (Айман, 44 года, педагог).

Г.С. «Как вы считаете, обрусевших городских казахов, говорящих на русском языке и слабо ориентирующихся в национальных обычаях и традициях, в целом, В казахской национальной культуре, можно ли обвинить в отсутствии патриотизма?»:

«В отсутствии патриотизма нет. Ну, вот отсутствие перспектив, то такая опасность есть. Выросиие в советском Усть-Каменогорске казахи просто не имели возможности освоить родной язык. Непонятно, откуда сейчас, уже в условиях независимости и подъема национального самосознания появляется поколение обрусевших казахов? Мне кажется, это непростительно» (Айман, 44 года, педагог).

«Прежде, чем говорить об отсутствии патриотизма у таких казахов, нужно разобраться в самом слове «патриотизм». Что оно обозначает? Любовь к чему или кому? Если я хороший работник, мама, приношу пользу этой стране, обществу, то, считаю, что я и есть патриот. Кстати, никуда уезжать из Казахстана я не собираюсь. Детей своих воспитываю нормально. Но не говорю я по-казахски, не говорю. И только из-за этого меня обвинять в том, что не патриот? A эти, значит, патриоты? Разворовывают страну, но при этом знают язык и все традиции соблюдают? Они патриоты?» (Сымбат, 48 лет, педагог).

Респондентам были также заданы вопросы, касающиеся досуга, музыкальных предпочтений и стиля одежды. Ответы демонстрируют преобладание современных установок у городских казахов над традиционными: «Слушаю рок, метал, джаз, раннюю попсу 30-40-х годов ... Стиль в одежде - казуально-городской, очень удобно. На работе - костюм ... В свободное время чаще всего смотрю футбол. У меня есть хобби фотосъемка. Часто совершаю прогулки по набережной города, фотографирую пейзажи, животных» (Амантай, 56 лет, педагог).

«Музыку слушаю разную, в основном зарубежную попсу. Иногда классику ... В одежде предпочитаю два стиля по ситуации: классический и спортивногородской. Второй стиль сейчас очень распространен. Удобно и соответствует ритму современного города ... Досуг предпочитаю проводить в тренажерном зале, кафре, сауне, ночных клубах или за шопингом. Типичный досуг типичного городского казаха. Иногда выезжаю на природу, посещаю читальный зал городской библиотеки» (Айман, 44 года, педагог).

В интервью также вошли вопросы на установки в межнациональном общении. Почти у всех респондентов есть среди друзей и родственников представители других национальностей. Отношение к межнациональным бракам от положительного, нейтрального до отрицательного: «Отношусь положительно, если обои - представители одной религии» (Тимур, 19 лет, студент), «Неоднозначно. Если, в межнациональной семье отец - казах, а мать русская, то почти всегда ребенок говорит по-русски и, несмотря на 
внешние особенности, будет и ментально русским» (Амантай, 56 лет, педагог), «Как правило, такие семьи часто разваливаются» (Зарина, 42 года, педагог).

Таким образом, ответы респондентов на представленный блок вопросов иллюстрирует наличие у них современных установок городской жизни. Данной группой городского населения практически не соблюдаются или соблюдаются формально национальные традиции и обычаи, общение поддерживается лишь с узким кругом близких родственников, почти во всех ситуациях отдается предпочтение русскому языку.

«Свои» и «чужие» в городском пространстве: особенности взаимодействия

Как указывалось выше, отдельный блок интервью составили вопросы, вскрывающие особенности взаимодействия исследуемой категории населения с другими группами казахов, проживающих в городе.

Г.С. «На ваш взгляд, можно ли назвать не так давно мигрировавших в город казахов-сельчан горожанами? Как вы думаете, сколько лет необходимо прожить в городе, чтобы считаться горожанином или в данном вопросе имеет значение не временной, а какие-либо другие критерии (нахождение человека в социальной или профессиональной нише, образовательный уровень, владение языком и пр.)?»:

"Только что переехавшие из села в город казахи еще не горожане. Для любого социального процесса, адаптации необходимо время. Сколько лет необходимо? Одно поколение должно вырасти. То есть у казахов-мигрантов должны родиться дети, которые социализировались бы в городе. Bom их уже можно будет назвать городскими жителями вполне. Мне кажется, нахождение человека в какой-то определенной социально-экономической нише, а также место его проживания, центр или пригород, ускоряют или, напротив, замедляют процесс адаптации к городу. Но эти признаки вторичны. Главное, поколение детей, рожденных и выросиих у мигрантовказахов в городе» (Айман, 44 года, педагог).

«Мне кажется, все зависит от того, с какой установкой человек переезжает в город. Если он хочет чего-то добиться, сделать карьеру там или разбогатеть, то он очень быстро станет городским. А если жить также как у себя в деревне, то он и будет деревенщиной до конца. Но это только мое мнение. Сейчас почти все бизнесмены - это же те, кто когдато из села переехал. Среди них мало коренных горожан» (Айжан, 46 лет, врач).

«10-15 лет достаточно чтобы стать городским. От человека зависит, от характера, круга общения. Многое зависит от того, где он будет работать - в образовании там или на рынке. Я сама не считаю тех, кто недавно прибыл в город городскими. Они выглядят по-другому, говорят в основном по-казахски. Да, и еще нас упрекают, что мы казахский не знаем хорошо» (Сымбат, 48 лет, педагог).

Ответы на представленный вопрос показывают, что опрашиваемые дистанцируются от не так давно мигрировавших казахов-сельчан, не считая их «своими», городскими, указывая на то, что для интеграции в городское пространство необходимо время, а также определенные условия.

Г.С. «Как вы считаете, интегрируются ли в социально-экономическое пространство города вчерашние сельские казахи?»:

«За всех говорить трудно. Часть казахов, особенно обрусевших, прибывших из русских сел или малых городов, районных центров быстро 
интегрируется. Вообще, для интеграции в городское пространство Казахстана главное, мне кажется, знание русского языка. Для тех, кто им владеет, процесс адаптации более безболезненный и скорый. Есть другая категория вчерашних сельчан, которая не интегрирована. Они ведут себя по-разному. Одни делают попытки. Другие, напротив, стараются изо всех сил показать, что город - это теперь их территория и жить они здесь будут по своим законам» (Айман, 44 года, педагог).

"Раньше все мои соседи были местные, казахи, там русские и прочие. Сейчас все чаще переезжают в наш дом из села или квартиру снимают. Сразу проблемы начинаются. То мусор в подъезде оставят, то половики трясут с лоджии, то ремонт нескончаемый у них, то шум всю ночь, разборки или музыка. Они как будто не понимают, что кругом люди, что мы жили по своим законам и нас все устраивало. Со своим уставом в чужой монастырь, получается. На мой взгляд, очень мало из них, кто действительно интегрируется» (Сымбат, 48 лет, педагог).

\section{Г.С. «Как строятся Ваши отношения с казахами, недавно} мигрировавшими из села?»:

«Нормально. Общаюсь с ребятами, которые из села приехали. Не так часто, но не конфрликтуем» (Тимур, 19 лет, студент).

«По-разному. В основном они говорят только по-казахски, поэтому мы не часто пересекаемся» (Лаура, 20 лет, студентка).

“Общаемся, конечно. Не знаю. Они те же казахи... пытаются выжить, устроиться, поэтому часто распихивают нас локтями» (Назерке, 20 лет, студентка).

«На работе часто пациенты - это бывшие сельчане. Вначале было сложнее, потому что языковой барьер мешал. Сейчас язык учу. Самое необходимое сказать им могу. Но они, какие-то, трудные, что ли. Мне с ними некомфрортно. Но из-за работы приходится» (Айжан, 46 лет, врач).

«Я живу на КШТ (Г.С.: пригород Усть-Каменогорска). Сейчас хочу переехать в город. На это есть несколько причин и одна из них - это мое окружение, соседи. КШТ в целом казахский район. Но казахи бывают разные. Если в центре КШТ живут те, которые переехали сюда еще в 70-80-е годы, то есть их можно назвать городскими. То на его окраине, в новостройке (там, где живу я), проживают вновь прибывшие, как правило, из аулов. Проблема даже не в том, что я не уживаюсь с ними. Просто мне здесь дискомфоортно. Не поймите меня не правильно. Я нормально отношусь ко всем представителям своего этноса. Приветствую то, что казахи, наконец, становятся городской нацией. $A$ процессы урбанизации титульного населения в республике могут обеспечиваться в большинстве своем выходцами из села. Понимаю, что на освоение бывшими сельчанами стандартов городской жизни, особенностей городской субкультуры, нужно время. Но как же быть тем, у кого эти процессы позади? И потом, ведь не все приехавшие в город понимают, что здесь многое строится по-другому. Или же, понимают, но не принимают. В общем, сложно. Мне проще переехать в город и оставаться там» (Айман, 44 года, педагог).

Ответы респондентов на данный блок вопросов показывают, что между городскими казахами и сельскими мигрантами существует дистанция. Первые не воспринимают вторых как полноправных городских жителей, более того, в ряде ответов респондентов отмечаются проблемы во взаимоотношении с мигрантами (в основном жилищно-бытовые). Указывается также все еще существующая проблема медленной адаптации в городе отдельной категории 
бывших сельчан. А в некоторых случаях - наличие установок на сохранение традиционного уклада и нежелание воспринимать стандарты городской жизни.

Этническая визуализация города: «за» и «против»

В интервью также вошли вопросы, характеризующие отношение респондентов к преобразованиям современного городского пространства: визуальным, ономастическим, этническим и прочим.

Г.С. «Как вы относитесь к тому, что в городе численность и удельный вес лиц казахской национальности с каждым годом увеличивается?»:

«Нормальный, эволюционный и закономерный прочесс. Если эмигрируют русские, значит, места и ниши в городе освобождаются. Их должен кто-то занять. А кто, кроме казахов в Казахстане это может сделать. Только они. Казахстан не Евросоюз или США, он не привлекателен для мигрантов, кроме репатриантов» (Айман, 44 года, педагог).

«Город же в Казахстане находится. Должны быть казахи, примерно, на 80\%» (Айжан, 46 лет, врач).

Г.С. «Ваше отношение к тому, что на улицах города всё чаще можно услышать казахскую речь?»:

«Ну, если, сельские казахи переезжают в город, а они носители в основном казахского языка. Отношение положительное. Казахи государствообразующий этнос республики. Значит, положено по статусу проживать в городах. Значит, в городском пространстве все чаще можно будет услышать казахскую речь» (Айман, 44 года, педагог).

«Многонациональность, полиязычность - это всегда хорошо» (Зарина, 42 года, педагог).

Как видно из ответов, несмотря на указанные выше определенные проблемы во взаимоотношениях, возникающие у городских казахов с сельчанами-мигрантами, первые приветствуют рост численности автохтонов в городах и распространение казахского языка в городском пространстве.

Г.С. «Суверенный период республики характеризуется активизацией миграционного потока село-город. Как вы считаете, не приведет ли данное явление к «затоплению» казахстанских городов сельскими мигрантами и есть ли необходимость в его ограничении?»:

"Ограничения необходимы в первую очередь в том случае, если город не в состоянии будет обеспечить всех сельских мигрантов работой. Именно сектор занятости, городская экономика должны явиться главным фрактором, причиной стимулирования или ограничения потока село-город. Однако не стоит сбрасывать со счетов опасность рурализации города. Мне кажется, такие тенденции в той или иной степени наблюдаются практически во всех городах страны. Обратная сторона медали. И без этого не обойдется. Часть городов еще продержится какое-то время, а потом потихоньку город будет меняться. Если не рурализация, то изменения, трансорормации все равно произойдут. Прежними города уже не будут. Это не только для Казахстана характерно. Вы посмотрите на Россию. Не только перифрерия, центральные города превращаются в какойто странный гибрид. У нас это только этнически окрашено, значит более гротескно» (Айман, 44 года, педагог).

«Конечно, если сельские потеснят городских, нужно будет ограничивать их миграцию. Я хотел сказать, что пусть приезжают, но только если это не будет во вред тем, кто живет в городе. Если всем им будет в городе работа» (Тимур, 19 лет, студент). 
«Допустим, в Семее очень много прибывших из аула. Ничего хорошего. Поток надо ограничивать уже сейчас. A то у нас будет тоже самое. A с другой стороны, во многих аулах жить трудно. И в городе есть такие профессии, на которые сами городские не согласятся» (Назерке, 20 лет, студентка).

В ответах респондентов прослеживается тесная взаимосвязь между сельско-городской миграцией и занятостью. В некоторых ответах указывается на опасность рурализации или «затопления» города в случае, если поток селогород не будет сдерживаться.

Г.С. «Какие изменения в городе произошли, на ваш взгляд, за последние 15-20 лет? Ваше отношение к ним?»:

«За последние 15-20 лет Усть-Каменогорск сильно изменился. Стало больше современных зданий, стали лучше дороги, больше транспорта. Этнические изменения произошли, увеличилось число казахов. Очень сильно разросся пригород. Я сама проживаю на КШТ и хочу отметить те изменения, которые произошли в нем. Во-первых, наладилась транспортная связь с городом. Во-вторых, застрачваются пустыри. Заполнение пустующих между городом и КШТ территорий происходит не только за счет воздвижения торговых иентров, но и за счет театров, спортивных комплексов, жилых домов. Радует тот фракт, что в пригород стали вкладывать средства. Постепенно КШТ фрормируется как самодостаточная территория, со своей экономической и социально-культурной инфраструктурой» (Айман, 44 года, педагог).

«Да, Усть-Каменогорск за последние 20 лет меняется в лучшую сторону. Город становится молодежным, много молодых семей, детей. Появились культовые здания - несколько мечетей и других храмов. Идет активная стройка» (Амантай, 56 лет, педагог).

Почти все респонденты отвечают изменения, произошедшие в городе за последние 20 лет: этнические, визуальные, ономастические и пр. В целом опрашиваемыми дается положительная оценка преобразованиям города.

Г.С. «Ваше отношение к ономастическим преобразованиям города, переименованию некоторых улиц, проспектов, площадей на казахский язык?»:

«Ономастические изменения являются характерными для современного Казахстана. Отношение положительное. Новые названия отражают как исторические процессы, так и реалии современности, то есть те преобразования, которые происходят в суверенном Казахстане. Например: проспекты Абая, Ауэзова, Сатпаева, Независимости, улицы Кабанбай батыра, Серикбаева, Астана и др. Я не считаю, что это казахизация, навязывание. Это правильно. Город находится на территории Казахстана, поэтому часть улиц должна носить казахские названия. Единственное, что если уж называть именем какого-то человека, то это должен быть достойный человек» (Айман, 44 года, педагог).

"В принципе я "за» переименование. Но это нужно делать без ошибок. Если уж взялись переименовывать с русского на казахский язык, то без ошибок. Например, переименовали улицу Космическая в улицу Ғарыштар. A если перевести слово ғарыштар на казахский язык, то оно обозначает слово космонавты. То есть получается улица Космонавтов, а не Космическая... Если решили увековечить имя человека в названии улицы, города или проспекта, то это должна быть личность, внесшая очень большой вклад в развитие страны. Не понимаю, зачем нужно было 
переименовывать улицу Мира в улицу Головкова. Что этот человек сделал такого неоценимого для нашего региона, что нужно было называть его именем улицу. И потом, название улицы Мира было понятно и близко каждому. Вообще лучше было бы, если в наименовании улиц фигурировали бы не имена, а какие-либо абстрактные названия. Например, улица Мира, Луговая, Большая, Тихая. А если уж называть улицы именами каких-либо людей, то только после глубокого анализа их вклада и деятельности. Конечно, нужно считаться и с мнением людей, проживающих на этих улицах. Вообще, считаю, что переименование улиц должно быть постепенным. Люди постепенно уходят, вместе с ними уходит эпоха, многие названия улии, парков, проспектов, которые отражали ценности уходящей эпохи, перестают быть актуальными или приобретают иной смысл. Вот тогда то и имеет смысл задуматься над переименованием»(Амантай, 56 лет, педагог).

«Сейчас очень много улии переименовывается не только в УстьКаменогорске, но и по всему Казахстану. Отношение к этому двустороннее. С одной стороны, я думаю, что не стоит переименовывать, потому что это наша история. A c другой стороны, все-таки, мы получили независимость, и достойные улицы можно переименовать. Но это очень расточительно. Иногда идешь по улице и не знаешь ничего о человеке, именем которого она названа. У меня пожелание, чтобы рядом с именем была табличка, историческая справка о том, что он сделал для Казахстана, для города» (Айжан, 46 лет, врач).

"Смена названий улиц приносит, прежде всего, финансовые проблемы. Это нужно принять очень много документации и, мне кажется, местное население все равно называет улицы по-старому» (Зарина, 42 года, педагог).

«Думаю правильно, например, парк им. Жамбыла. Надо называть улицы именно такими людьми, которые прославили наш народ. Например, Абай. Отношение нейтральное, скорее всего. Называть можно героями Советского Союза, именно казахами. Через 20 лет наши дети будут узнавать через названия улиц об этих людях, будут заинтересованы» (Лаура, 20 лет, студентка).

«Некоторым улицам было бы правильнее сохранить русское название, т.к. многие названия улиц на казахском языке или не понятны, или с ошибками» (Назерке, 20 лет, студентка).

Г.С. «Ваше отношение к переименованию города Усть-Каменогорск в Өскемен (Семипалатинск в Семей)?»:

«C одной стороны, Усть-Каменогорск, в целом двойные названия городов, сложны как в произношении (особенно для казахоговорящих), так и в написании. Можно было бы и подсократить. Но, с другой стороны, это историческое первоначальное название города. Не многие города и прочие населенные пункты могут этим похвастать. Может сохранить его? Также названия Семей, Өскемен - это слова-кальки, они не имеют определенного значения, смысла, в казахском языке таких слов нет и не было. Если что-то бы зависело от переименования, например, повышение экономического или социального уровня жителей города. А так... Семипалатинск, вот, переименовали и что, проблемы то остались. Ничего не изменилось. Единственное, в сознании казахов, особенно сельских мигрантов, наступило какое-то удовлетворение, успокоение, что они живут в городе, названным по-казахски» (Айман, 44 года, педагог). 
«Форсирование в топонимике опасно и нежелательно. Вопрос болезненный, особенно для коренных русских горожан» (Амантай, 56 лет, педагог).

«В Өскемен хотят переименовать? Впервые слышу ... Так многие казахи и называют город как Өскемен. То есть хотят официальное название дать? Ну, я даже не знаю. Честно, не знаю, что сказать. А что, оm нашего мнения что-то зависит? Если да, по можно назвать Өскеменом» (Тимур, 19 лет, студент).

«Ты откуда? C Устькамана - звучит. А с Өскемена не звучит. Ну, как то нейтрально» (Лаура, 20 лет, студентка).

«Можно будет переименовать, но многие, особенно русские, все равно будут называть по-старому» (Зарина, 42 года, педагог).

Г.С. «Как вы относитесь к тому, что ономастические преобразования коснулись Усть-Каменогорск в меньшей степени, в сравнение со многими городами республики, и большая часть улиц города имеет прежнее название?»:

«Опять-таки, многое зависит от этнической структуры. В городе попрежнему много русского населения. Вообще, в Казахстане названия населенных пунктов, улиц - это не просто названия, но и этнические идентификаторы, особенно сейчас. В населенных пунктах, сохранивших русское название, проживает преимущественно русский этнос или же его численность существенна, и наоборот» (Айман, 44 года, педагог).

«Лет десять назад в стране была мода на переименования. Сейчас вроде стихло. Но мне удобнее прежние названия, поэтому отношусь положительно» (Сымбат, 48 лет, педагог).

«Надо переименовать еще часть улиц, но и прежние названия, самые красивые, оставить. Мне кажется, в Усть-Каменогорске должно быть больше улиц на казахском языке. А магазины, кафе пусть называются поразному» (Тимур, 19 лет, студент).

Что касается ономастических преобразований, то в данном вопросе мнения респондентов разделились. Часть опрашиваемых относятся к переименованиям положительно, другая часть, напротив, предлагает сохранить старые названия улиц и прочих городских объектов. Тем не менее, и те, и другие сходятся во мнении, что процесс переименования должен быть постепенным, с учетом мнений всех жителей города, сопровождаться глубоким анализом.

Г.С. «Что для вас значит Усть-Каменогорск?»:

«Усть-Каменогорск для меня лично - это город моей молодости. Это город, где живут мои друзья. Он ближе мне, чем остальные города Казахстана, мира» (Айман, 44 года, педагог).

«Для меня город Усть-Каменогорск - город детства» (Тимур, 19 лет, студент).

«Это мой родной город. Я живу здесь с 1981 г. По значимости для меня он на первом месте, потом Алматы» (Амантай, 56 лет, педагог).

«Я живу в Усть-Каменогорске давно и, если бы меня поселили в Шымкенте, я бы там не смогла жить. Мне нравится больще тут» (Назерке, 20 лет, студентка).

«Устькаман для меня - это моя малая родина, это самый лучший город, несмотря ни на что» (Зарина, 42 года, педагог).

В ответах респондентов, характеризующих место города в их жизни, встречаются словосочетания «город детства», «город молодости», «моя малая 
родина», «самый лучший город». То есть для опрашиваемых Усть-Каменогорск является родиной, а сами они считают себя полноправными жителями этого города.

Заключение. Рурализация, русификация, аккультурация: на перепутье траектории будущего. Таким образом, ответы респондентов, представляющих когорту ассимилировавшихся и интегрировавшихся в городе казахов, позволяют сделать следующие выводы. Практически все они являются носителями современных установок городской жизни, демонстрируют современные городские поведенческие модели, транслирующиеся через отношение к соблюдению (точнее, несоблюдению) большей части национальных традиций, языковые предпочтения. Что касается предпочтений в одежде, проведения досуга, хобби, выбора литературы и музыки, то данная группа казахского населения полностью соответствует современным городским стандартам.

Отношения с представителями других групп городского казахского населения выстраиваются в целом положительно. Однако почти все респонденты отметили возникающие при этом проблемы (бытовые, социальные, экономические). В тоже время большая часть опрашиваемых приветствует увеличение численности казахов в городе, с оговоркой на опасность возможных последствий рурализации.

Отношение к ономастическим преобразованиям неоднозначное. Поддерживая необходимость таких изменений в независимом Казахстане, в тоже время респонденты данной группы горожан медленно адаптируются к новым названиям улиц, предпочитая использовать прежние. Более того, часть представителей отмеченной категории населения считают старые названия улиц, проспектов и площадей частью истории страны. Допускают лишь переименование тех названий, которые утратили свою актуальность или же никак не связаны с историей и современностью Казахстана.

Таким образом, в жизни современного казахстанского города все вышеотмеченные слои казахов-горожан занимают определенное место и взаимодействуют друг с другом. Создается своего рода симбиоз из различных групп казахского городского населения, а также представителей других этносов, проживающих в городах. Сказанное служит причиной проявления непростых, в чем-то противоречивых, а где-то и опасных тенденций в современном казахстанском городе.

Нет необходимости доказывать, что урбанизация глубоко позитивный процесс. Чем выше показатели урбанизированности того или иного общества, тем выше уровень экономической, социально-политической, правовой и прочих культур. Города - сосредоточение новейших технологий, именно здесь вырабатываются и распространяются интеллектуальные новации, здесь формируется плотное информационное поле. Урбанизация выступает синонимом прогресса, ибо действительно современная цивилизация начинается с городов, а большинство видов деятельности и явлений имеет в качестве своей основы городскую жизнь. Не случайно, ускоренная урбанизация является одним из ведущих приоритетов в стратегическом развитии Казахстана, нацеленного на модернизацию и «встраивание» в мировую экономику. На повестке дня стоит проблема снижения в валовом национальном продукте доли сельского хозяйства, сокращения населения, занятого в нем. В Послании Главы государства «Рост благосостояния казахстанцев: повышение доходов и качества жизни» говорится: «На сегодня экономики ведущих стран в большей степени представлены глобальными 
городами или мегаполисами. Более $70 \%$ мирового ВВП создается в городах». (Назарбаев, 2018)

Однако нельзя отрицать и другую сторону процесса урбанизации. Речь идет о порождении ею социальной, экономической и психологической напряженности и дестабилизации. Необходимо помнить о том, что урбанизация может выступать не только фактором консолидации того или иного этноса или нации, но и способствовать их «разлому», создавать препятствия для эффрективного национального строительства.

В силу сказанного нельзя сбрасывать со счетов диффееренцированность городского населения республики. На сегодняшний день в городах Казахстана сложилась ситуация, когда «...основными частями конструкта «суверенное городское пространство» становятся, с одной стороны, вчерашние сельские жители, в основном - казахи. С другой стороны, давно населяющее города европейское население (прежде всего русские). Между ними находились стремящиеся определить свою цивилизационную идентичность русифицированные городские казахи». (Алексеенко, 2016:8)

В целом, в процессах урбанизации казахов существует две крайности, которые хотелось бы избежать в будущем. Первая - это русификация казахского городского населения, растворение этнической самобытности и языка в городском пространстве (движение от традиционного к современному). Данное опасение имеет под собой основание, т.к. русский язык не утратил своей актуальности в городе и по сей день, доказывая тем самым живучесть и конкурентоспособность. Складывается противоречивая ситуация - когда этническая основа практически сведена к минимуму, а язык продолжает быть актуальным.

Ещё один, на наш взгляд, нежелательный сценарий дальнейшего освоения городского пространства - рурализация города (движение от современного к традиционному), что также имеет место отчасти в г. Усть-Каменогорске, в большей степени - в пригороде. Когда городское сознание, городская субкультура и образ жизни не могут устоять перед корпоративными возможностями бывших сельчан в силу их многочисленности, компактности проживания, а также представленности в определенных сферах экономики страны. Когда город начинает жить не по устоявшемуся стандарту и привычной логике городского развития, а по ситуации, в которой современное городское мышление всё чаще уступает место родовому.

Существует также и третий вариант развития урбанизационных процессов: на основе прежней социальной структуры города - трансформация его отдельных элементов (этнических, культурных, экономических), создающая предпосылки для дальнейшего развития. При данном сценарии возможен синтез взаимного сосуществования в одном городском пространстве как русского языка и культуры, так и казахского, отчасти, с элементами вестернизации.

На наш взгляд, тенденции развития этого сценария также можно наблюдать в г. Усть-Каменогорске: «... уже сейчас видно, что формирующийся социальный строй способен стать своеобразным «хранителем функций города», неким инвариантом городского существования. Он сдерживает эмиграционные настроения русскоязычных, а прибывающие в город сельские мигранты адаптируются к особенностям жизнедеятельности именно этого «пространства». (Алексеенко, 2016:9)

Траектория развития урбанизационных процессов в каждом городе Казахстана индивидуальна. На взгляд автора, для дальнейших эволюций 
городского пространства наиболее благоприятен третий сценарий, ведущую роль в котором в состоянии играть городские казахи, способные объединить и консолидировать казахстанские «параллельные миры».

\section{Әдебиеттер тізімі/ Список литературы}

1. Сарсембаева Г.А. Особенности процессов урбанизации казахского этноса в современный период // Сб. науч. трудов IX Международ. науч.-практ. конф., 16-17 мая 2008 г., г. УстьКаменогорск, $2008-400$ c.

2. Статистический сборник по отдельным показателям всесоюзных переписей населения 1939, 1959, 1970, 1979, 1989 гг. Алма-Ата, 1991.

3. Национальный состав населения Республики Казахстан. том 2. Население Республики Казахстан по национальностям и владению языками / Итоги переписи населения 1999 года в Республике Казахстан. Статистический сборник. / Под ред. А. Смаилова /. - Алматы, 2000.

4. Этнодемографический ежегодник Казахстана. Статистический сборник. /Под редакцией Шокаманова Ю.К./ Алматы, 2006.

5. Перепись населения Республики Казахстан 2009 года. Краткие итоги. Статистический сборник /Под ред. А.А. Смаилова/ Астана, 2010 - 110 с.

6. Назарбаев Н. В каждом сердце - родная страна: речь на 12-й сессии Ассамблеи народа Казахстана // Казахстанская правда, 25 октября 2006 г.

7. Итоги Всесоюзной переписи населения 1959 г. Казахская ССР. 1962. М. 1991.

8. Данные Восточно-Казахстанского областного управления статистики: Усть-Каменогорск,

9. Этнодемографический сборник Республики Казахстан. 2014. Агентство РК по статистике. Астана, 2015.

10. Назарбаев Н.А. Рост благосостояния казахстанцев: повышение доходов и качества жизни // Казахстанская правда 5 октября 2018 г.

11. Алексеенко А.Н. Место встречи Усть-Каменогорск: два мира, два образа жизни в поисках взаимодействия и сотрудничества. - Астана-Алматы, 2016, 144 с.

\section{References}

Sarsembaeva, 2008 - Sarsembaeva, GA. 2008 Osobennosti processov urbanizacii kazahskogo ehtnosa v sovremennyj period // Sb. nauch. trudov IX Mezhdunarod. nauch.-prakt. konf., 16-17 maya 2008 g., g. Ust'-Kamenogorsk. 400 s. (in Rus).

Statisticheskij, 1991 - Statisticheskij sbornik po otdel'nym pokazatelyam vsesoyuznyh perepisej naseleniya 1939, 1959, 1970, 1979, 1989 gg. Alma-Ata. (in Rus).

Nacional'nyj, 2000 - Nacional'nyj sostav naseleniya Respubliki Kazahstan. tom 2. Naselenie Respubliki Kazahstan po nacional'nostyam i vladeniyu yazykami / Itogi perepisi naseleniya 1999 goda v Respublike Kazahstan. Statisticheskij sbornik. / Pod red. A. Smailova /.Almaty. (in Rus).

EHtnodemograficheskij, 2006 - EHtnodemograficheskij ezhegodnik Kazahstana. Statisticheskij sbornik. /Pod redakciej SHokamanova YU.K./ Almaty. (in Rus).

Perepis', 2010 - Perepis' naseleniya Respubliki Kazahstan 2009 goda. Kratkie itogi. Statisticheskij sbornik /Pod red. A.A. Smailova/ Astana. 110 s. (in Rus).

Nazarbaev, 2006 - Nazarbaev, N 2006 V kazhdom serdce - rodnaya strana: rech' na 12-j sessii Assamblei naroda Kazahstana // Kazahstanskaya pravda, 25 oktyabrya 2006 g. (in Rus).

Itogi, 1962 - Itogi Vsesoyuznoj perepisi naseleniya 1959 g. Kazahskaya SSR. M. (in Rus).

Dannye, 1991 - Dannye Vostochno-Kazahstanskogo oblastnogo upravleniya statistiki: Ust'Kamenogorsk. (in Rus).

EHtnodemograficheskij, 2015 - EHtnodemograficheskij sbornik Respubliki Kazahstan. 2014. Agentstvo RK po statistike. Astana. (in Rus).

Nazarbaev, 2018 - Nazarbaev, N 2018 Rost blagosostoyaniya kazahstancev: povyshenie dohodov i kachestva zhizni // Kazahstanskaya pravda 5 oktyabrya. (in Rus).

Alekseenko, 2016 - Alekseenko, A 2016 Mesto vstrechi Ust'-Kamenogorsk: dva mira, dva obraza zhizni v poiskah vzaimodejstviya i sotrudnichestva. - Astana-Almaty. 144 s. (in Rus). 